\title{
Applying GIS in Analysing Black Spot Areas in Penang, Malaysia
}

\author{
Tarmiji Masron, Wan Muhammad Taufik Wan Hussin, Mohd Norarshad Nordin, Nur \\ Faziera Yaakub and Mohd Azizul Hafiz Jamian
}

Received: 2017-08-13 /Revision: 2018-07-13/ Accepted : 2018-08-01

(c) 2018. Faculty of Geography UGM and The Indonesian Geographers Association

\begin{abstract}
This study aims to analyze fatal accident rate involving all vehicle types in the North East District of Penang. It covers fatal accident data within the duration of three years from 2011 till 2013. The primary objective is to analyze the spatial pattern and fatal accident black spot areas using Geographic Information System (GIS) application. Average Nearest Neighbor (ANN) tool is used to analyze fatal accident spatial pattern, while Kernel Density Estimation (KDE) method is utilized for fatal accident analysis. The Fatal Accident rates in 2011, 2012 and 2013 were the highest with each accounted up to 90, 88 and 91 cases. The result of ANN shows that the fatal accident pattern for 2011, 2012 and 2013 is clustered with null hypothesis rejected. The KDE analysis result shows that most fatal accident black spot areas happened at main road areas or segments.
\end{abstract}

Keywords: Fatal accident, GIS, spatial pattern, black spot, Kernel

Abstrak Penelitian ini bertujuan untuk menganalisis tingkat kecelakaan fatal yang melibatkan semua jenis kendaraan di Kabupaten Timur Laut Penang. Ini mencakupi data kecelakaan fatal dalam tiga tahun dari 2011 hingga 2013. Tujuan utamanya adalah untuk menganalisis pola ruangan dan area bintik hitam kecelakaan menggunakan aplikasi Sistem Informasi Geografis (SIG). Average Nearest Neighboor (ANN) digunakan untuk menganalisis pola spasial dari kecelakaan fatal, sementara Kernal Density Estimation (KDE) metode digunakan untuk analisis kecelakaan fatal. Tingkat kematian pada tahun 2011, 2012 dan 2013 adalah yang tertinggi dengan masing-masing berkontribusi hingga 90, 88 dan 91 kasus. Hasil ANN menunjukkan bahwa pola kecelakaan fatal untuk 2011, 2012 dan 2013 dikelompokkan dengan menolak "hipotesis nol". Hasil analisis KDE menunjukkan bahwa lokasi utama kecelakaan fatal terjadi di jalan atau segmen utama.

Kata kunci: Kecelakaan fatal, GIS, pola spasial, titik hitam, Kernel

\section{Introduction}

Generally, urbanisation involves the shift in population from rural to urban settlements (McGranahan \& Satterthwaite, 2014). In Malaysia, urbanization refers to the gazetted area and the criteria used in 1970, 1980, 1991 and 2000 Population Census (Masron et al., 2012). The area gazetted as urban areas must have a population of 10,000 and more and gazetted areas with their adjoining built-up areas and the combination of both areas have a total population of 10,000 or more when the Population Census 2000 was conducted (Department of Statistics, 1995 \& 2001). According to the Global Road Safety Report, it is stated that there are more than 1.2 million victims of accidents every year, and nearly 50 million people are injured on roads (WHO, 2009). Based on the statement by Masron et al. (2012), Department of Statistics, 1995 \& 2001 and WHO (2009), it gives an idea that the higher the number of people, the higher the number of accident cases. Meanwhile, Road Safety Annual Report 2014 shows that the success in reducing road accidents at the global level is still low, although there is an increase in world mobility which is 0.6 percent between 2011

O2018 by the authors. Licensee Indonesian Journal of Geography, Indonesia.
This article is an open access article distributed under the terms and conditions of the Creative Commons This article is an open access article distributed under the terms and conditions
Attribution(CC BY NC) license. https://creativecommons.org/licenses/by-nc/4.0/.

Tarmiji Masron, Wan Muhammad Taufik Wan Hussin, Mohd Norarshad Nordin, Nur Faziera Yaakub and Mohd Azizul Hafiz Jamian

Centre for Spatially Integrated Digital Humanities, Faculty of Social Sciences and Humanities Universiti Malaysia Sarawak (UNIMAS), 94300 Kota Samarahan Sarawak Malaysia

Correspondent email: mtarmiji@unimas.my and 2012 (OECD, 2014). Analyzing road accidents is a complex process as the researches are from various backgrounds, including engineering, geography, as well as human behaviors (Sabel et al., 2005).

However, the main influencing factors can be classified into three categories, which are road engineering and traffic conditions, vehicle features and capacities, as well as drivers' behaviors and performance. Various improvements have been made, and steps are taken to reduce the number of road accidents, particularly in the aspects of better road safety and safer vehicle design, but the most significant elements in overcoming this problem are the behavior and performance of the drivers (Clinton \& John, 2013).

The study finds that traffic engineering and road network feature operations are the background and context that need to be taken into consideration in the aspects of road safety (Brockenbrough, 2009). Elvik et al. (2009) also find that in a road engineering global study, the best safety priorities include separating traffic on both directions according to the types of vehicles, having better junction design, creating safety monitoring and improving black spot areas, as well as traffic signage along the roads.

Moreover, in examining the Road Accident Theory, it is also significant to also look into Human Behavior General Theory which shows that drivers do not adhere to road safety rules while driving. Many researchers 
agree that the insouciant attitude of drivers as the main factor that causes road accidents. Among the models that could be referred in identifying human behaviors is through Interface Theory, which illustrates a general model of human driving behaviors (Fuller, 2000; Fuller \& Santos, 2002). According to the model, the task difficulty level can be identified from a dynamic interface which is between the demand of the driving task and the ability of the driver. If the ability surpasses the demand, hence the driving task becomes easy; whereas, if the ability is at par with the demand, the driver is considered to be at the maximum level of his driving capability, which is at a difficult driving level. The situation becomes worse if the demand surpasses the capability as a person with this level of driving capability could cause driving failure where he could lose control of the vehicle, and the unfortunate situation where a collision could occur or the vehicle could skid off the road.

Currently, the use of GIS has increased among agencies that manage the road network system for the purpose of analyzing road accident data. Identifying problematic road locations is the most important aspect in an accident case study. Although there is no international standard definition in identifying areas with frequent road accident occurrences, in the study conducted by Mark et al. (2013), the term "black spot area" is used to differentiate road area that has higher accident total with other areas. In another research by Oulha et al. (2013), two approaches are utilized in identifying black spot areas where road accidents occur which are through analyzing object and human movement analysis approach, as well as Kernel Density Estimation analysis approach. Based on the analysis, the black spot areas are identified by taking into account areas having repeated accidents of three to five cases a year.

In previous studies, there are different definitions of "black spot areas" among researchers. This could be due to various factors, such as the number of cases or accident locations, the width of the study area, etc. Nordin and Masron (2016) state that the use of GIS in determining the hot spot area can aid organizations to solve the occurrence problem.

Based on a study done by Apparao \& Mallikarjunareddy (2013), "black spot area" is defined as a location that is either a stretch or a spot that has abnormal (high) frequency total, in comparison to other areas. However, in a study done by Yue \& Zhang (2001), it is stated that the marking of "black spot area" is the most effective way in identifying an area or place that has high risk. This "black spot area" is used in identifying areas with frequent criminal cases, accident cases and others. This study also states that the principle in using black spot method is to assume that an affected area or site must have enough accident total or sample points to determine any type of accident pattern and has accident total that is similar in type, as well as the data on accidents must be able to be mapped based on a certain platform.

In addition, Yang et al. (2013) highlight an approach in identifying an area that has the potential of accident occurrence, as well as loss total caused by the accidents. The research result shows that the accident rate and economic cost due to traffic accidents are high in St. Louis Country and St. Louis City and most accidents that occurred was at junction areas and changes in traffic direction. Rankavat \& Tiwari (2013), on the other hand, calculate accident density within 50 meter radius with the size of 1 square kilometer. The research result shows that the accident density that involved pedestrians is high in Delhi area, which has high population density.

\section{The Methods}

This study focuses on the North East District of Penang. Based on Figure 1 below, the study area is part of the island with the width of 121 square $\mathrm{km}$, and it is connected to Seberang Perai through the Penang Bridge. The location of the area is at $5^{\circ} 22^{\prime} 16.28^{\prime \prime} \mathrm{N}$ latitude and $100^{\circ} 14^{\prime} 14.22^{\prime \prime}$ E longitude. The North East District is the most developed and populated area in Penang. The local authority for this district is City Council of Penang Island. The district is divided into 7 mukim (counties) which are Mukim 13, Mukim 14, Mukim 15, Mukim 16, Mukim 17, Mukim 18 and George Town City. Other than that, the district had a total of 508181 population with a density of 4200 people per square kilometer in 2010. The total for overall fatal accidents within the district in 2011, 2012 and 2013 were 90, 88 and 91 cases each. The total fatal accidents in North East District were the second highest in Penang after Central Seberang Perai District with 101, 115 and 101 cases for each year in 2011, 2012, and 2013. This district also has 13 police border areas and 83 police sector areas. Among the police stations included in the study area are Lebuh Pantai, Dato Keramat, Central, Patani Road, Kampung Baru, Batu Feringghi, Tanjung Tokong, Ayer Itam, Bandar Baru, Komuniti Taman Desa Permai, Jelutong, Sungai Nibong, and Pulau Tikus Police Stations.

Among the data used is spatial data that include accident area coordinate, state map, district map, polis station border map, as well as sector border map. Meanwhile, attribute data needed include information on accident details, such as time, month, year and type of accidents that happened. The spatial and attribute data, such as accident area coordinate, as well as the details on accidents were obtained from Penang Police Contingent Headquarter, while other information such as the state map, district map, police station, and sector border maps were obtained through the digitalizing process. Raw data obtained from the police was inserted into Microsoft Office Excel before loading it into GIS software for analysis. This was done as the storing data using this format was safer and easier, and it was able to be loaded directly into the GIS software when needed 


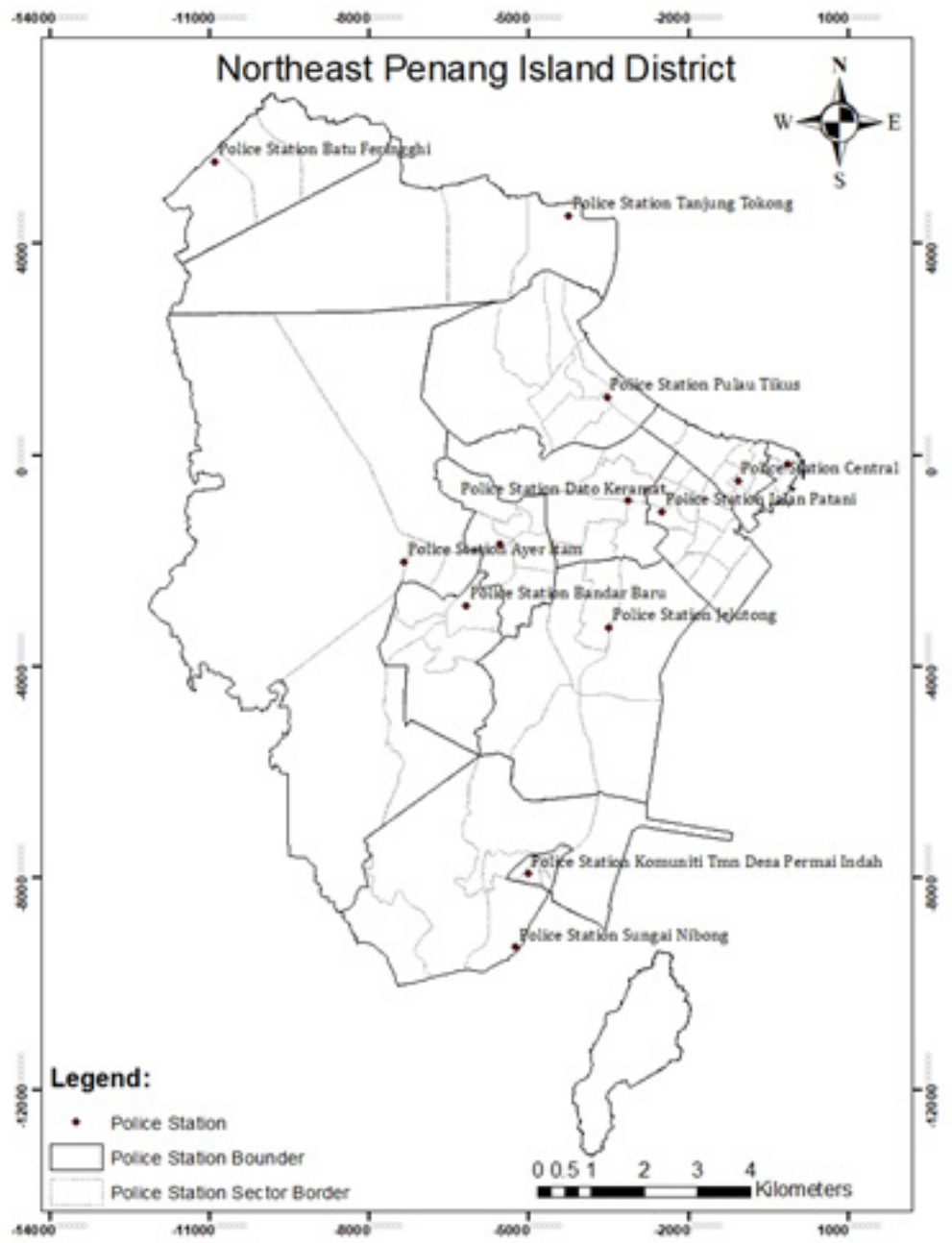

Figure 1. Study Area Map, Penang North East District

for analysis purpose. This research uses ArcGIS 10.1 software for analysis. There is two main analysis used for this research to obtain the output for discussion on each objective laid out in this research.

To analyze the road accident spatial pattern in Penang North East District, the researcher used the Average Nearest Neighbor (ANN) method that is available in the GIS application. This analysis method could calculate the nearest neighbor index based on the nearest neighbor feature average distance. The value of Nearest Neighbor Index, $\mathrm{z}$-score and p-value are the output values. P-value and $\mathrm{z}$-score are important measurements in statistics which determine whether the obtained value is a significant or insignificant value that would enable the researcher to accept or reject the null hypothesis by accepting hypothesis "A' (Salleh et al., 2012). This research uses the nearest neighbor average analysis to analyze the spatial pattern of fatal accidents in North East District using coordinate location data for each fatal case.

Distance analysis calculates the statistics not only based on incident spot location, but also between the spots (Naik et al., 2013). The Nearest Neighbor average is used to evaluate whether the incident of a fatal accident is clustered or not. It also calculates the distance between each centroid and the centroid feature that is nearest to it. The nearest distance average ratio is considered as the estimated distance average which is the estimated distance based on the random distance distribution hypothesis and the features total that covers the same area (Naim et al., 2013). If the index where the nearest neighbor average ratio is less than 1 , the inclination is towards clustered pattern; whereas if the index is bigger than 1 , the inclination is more towards scattered.

The second analysis method is the Kernel Density method which is used to analyze black spot areas involving road accidents in Penang North East District. This estimation method is chosen due to its ability to calculate the spot features density in the certain nearby area along the road in the study. This is suitable for the study because the definition of black spot areas that are used in the study is based on highest accident case density that happened at certain road parts, in 
comparison to other parts within 500 meter search radius. The definition is used because the data for the existing accident case total for the study areas is not suitable for the black spot area location determination based on the existing standard used by the Malaysian Road Work Ministry where the road accident black spot area is defined as the part of road that has the frequency of 3 accident cases within the duration of three consecutive years.

However, the definition of black spot area that is used by the researcher is aligned with the definition used by Mark et al. (2013) which describe the term as the section of a road that has a total number of accidents that is higher than another area. Other than that, based on the research that is done by Apparao et al. (2013) entitled, Identification of Accident Black spots for National Highway Using GIS, also uses a description that is almost similar which defines location either as the stretch or the spot that has the frequency total that is not normal (high) in comparison to other area assumed as a black spot area.

\section{Result and Discussion}

Based on Figure 2 below, spatial data analysis for fatal accident type in 2011 by using the ANN method shows that the spatial pattern is clustered. ANN output shows that the nearest neighbor average ratio is less than 1 , which is 0.646811 with the incident distance average between fatal accident cases within the study area is 418 meter. Based on the result, the fatal accident case spatial pattern is considered as clustered with the z-score value obtained is $\quad-6.480851$ with the p-value of less than 0.01 . So, the "A" hypothesis, which states that there is a spatial pattern for fatal accident cases for 2011, is accepted, whereas the null hypothesis is rejected. It is concluded that the output obtained for fatal accident cases at certain roads in the North East District area in 2011 shows clustered spatial pattern.

By referring to Figure 3 below, the same output is obtained for fatal accident case spatial data for 2012 through the use of the ANN method. The result obtained shows that the nearest neighbor average ratio is less than 1 , which is 0.623458 with the incident distance average between fatal accident cases in the study area is 413 meter. Hence, it can be stated that the fatal accident spatial pattern for 2012 is clustered. This is proven by the $\mathrm{z}$-score value obtained which is- 6.602123 with the p-value which is less than 0.01 . Therefore, the "A" hypothesis which states that there is a spatial pattern for fatal accident cases for 2012 is accepted; whereas the null hypothesis is rejected. In conclusion, the finding obtained for 2012 on fatal accident cases still shows fatal accident spatial pattern that is similar to the previous year.

The ANN analysis output for the fatal accident case spatial data for 2013 also shows the same pattern with the years earlier which is clustered. Based on Figure 4 below, the nearest neighbor average ratio is less than 1 , which is 0.681886 with the incident distance average between the fatal accident cases within the study area is 467 meter; whereas the $\mathrm{z}$-score value is -5.544377 and the p-value is less than 0.01 . Thus, the "A" hypothesis which states that there is a spatial pattern for the fatal accident for 2013 is accepted; whereas the null hypothesis is rejected. In conclusion, the obtained output for the duration of three consecutive years clearly shows that the pattern for fatal accidents that happened is clustered.

The research on fatal accident black spot areas for the duration of three years based on Table 1 and Figure 5 below is at the area from Sultan Azlan Shah Road to Utara Road junction at Masjid Negeri Road area; at the exit to the Penang Bridge; at the Residensi Road area from Macalister Road roundabout until the junction towards Tull Road; and the area where Jalan Kelawei begins from Jalan Bangkok junction until Maktab Road junction.

\section{The Research Duration Fatal Accident Black Spot Area}

Figure 6 to Figure 8 show the fatal accident black spot areas according to months which are the month of January until April, May until August, and September until December which is within the three years duration of the research. Based on Figure 6 and Table 2, among the fatal accident black spot areas within the first month include: the exit to the Penang Bridge area; Thein Teik Highway area from Beriksa 3 Street junction to Medan Angsana 1 Street junction; Jelutong Road area from Bakau Street junction until Hala Sungai Pinang; C.Y. Cyoi Road area from Macallum Street intersection until Gat Noordin Street intersection; Residensi Road area from Macalister Road roundabout until Tull Road junction; and Paya Terubong Road area from Bukit Jambul junction until Relau Road junction.

The areas that have high density clusters which are the black spot areas within the second month are shown in Figure 7. Table 3 list the areas which are at Jalan Sultan Azlan Shah area from Utara Road junction until Jalan Tengku Kudu junction at Gelugor Road area; Masjid Negeri Road area from Persiaran Mas junction until Pinhorn Road junction; and Jalan Kelawei area from Maktab Road junction until Bangkok Lane junction.

Fatal accident black spot areas within the third month is illustrated in Figure 8 and Table 4 shows the areas which are: at Thein Teik Highway area from Jalan Tun Mohd junction until Zoo Road junction; Utama Road area from Brook Road intersection until Jalan Scotlan intersection; and along Jalan Thein Teik.

The fatal accident black spot areas during daytime mostly happened at Tun Dr LCE Highway road area from Cecil Street intersection until Noordin Street intersection; along Jalan Penang from Dato Keramat Road intersection until the left exit towards Burma Road; Paya Terubong Road area from the junction towards Bukit Kukus Lane until Tingkat Paya 


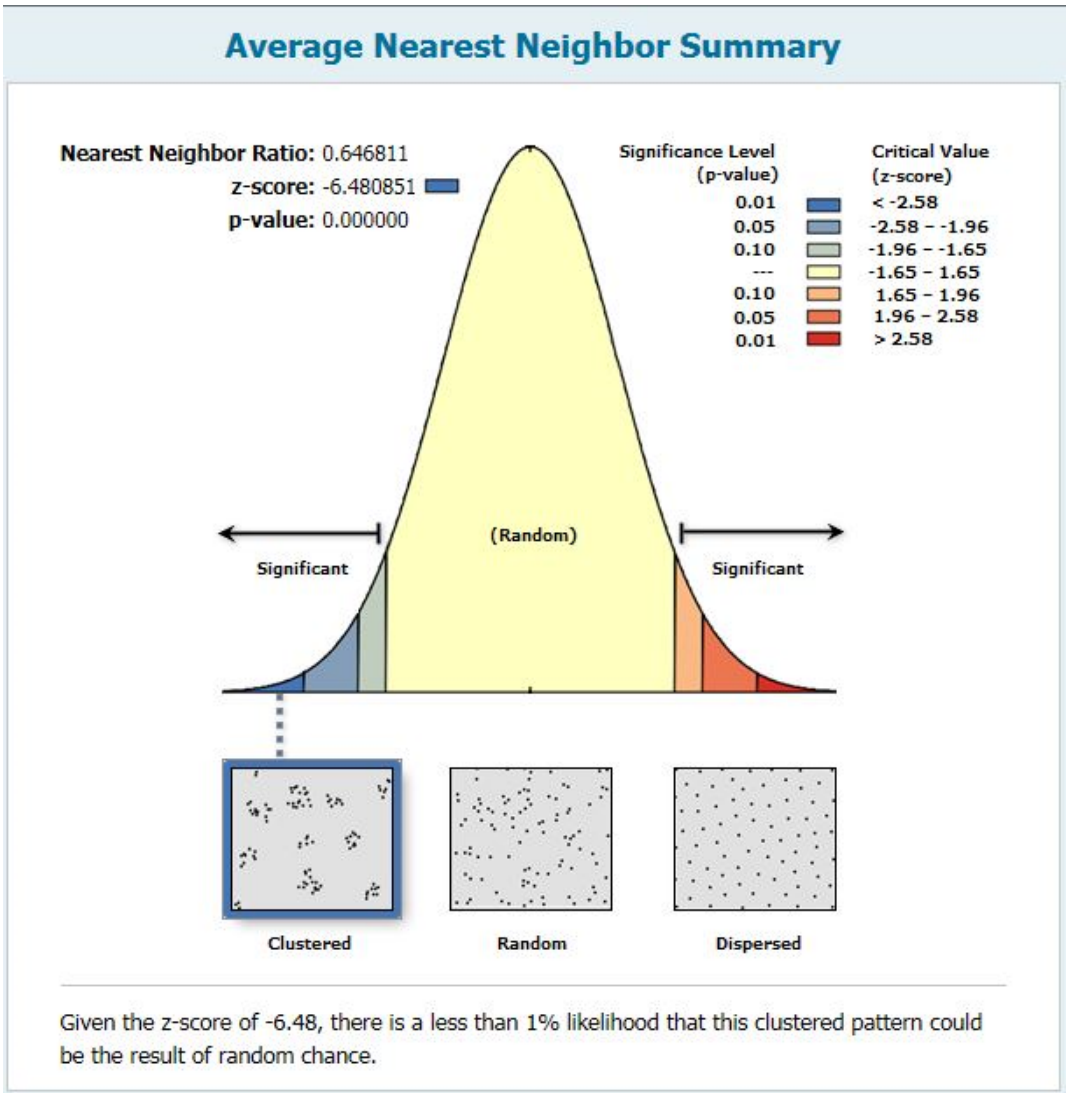

Figure 2. Fatal Accident ANN Analysis Output in North East District for 2011

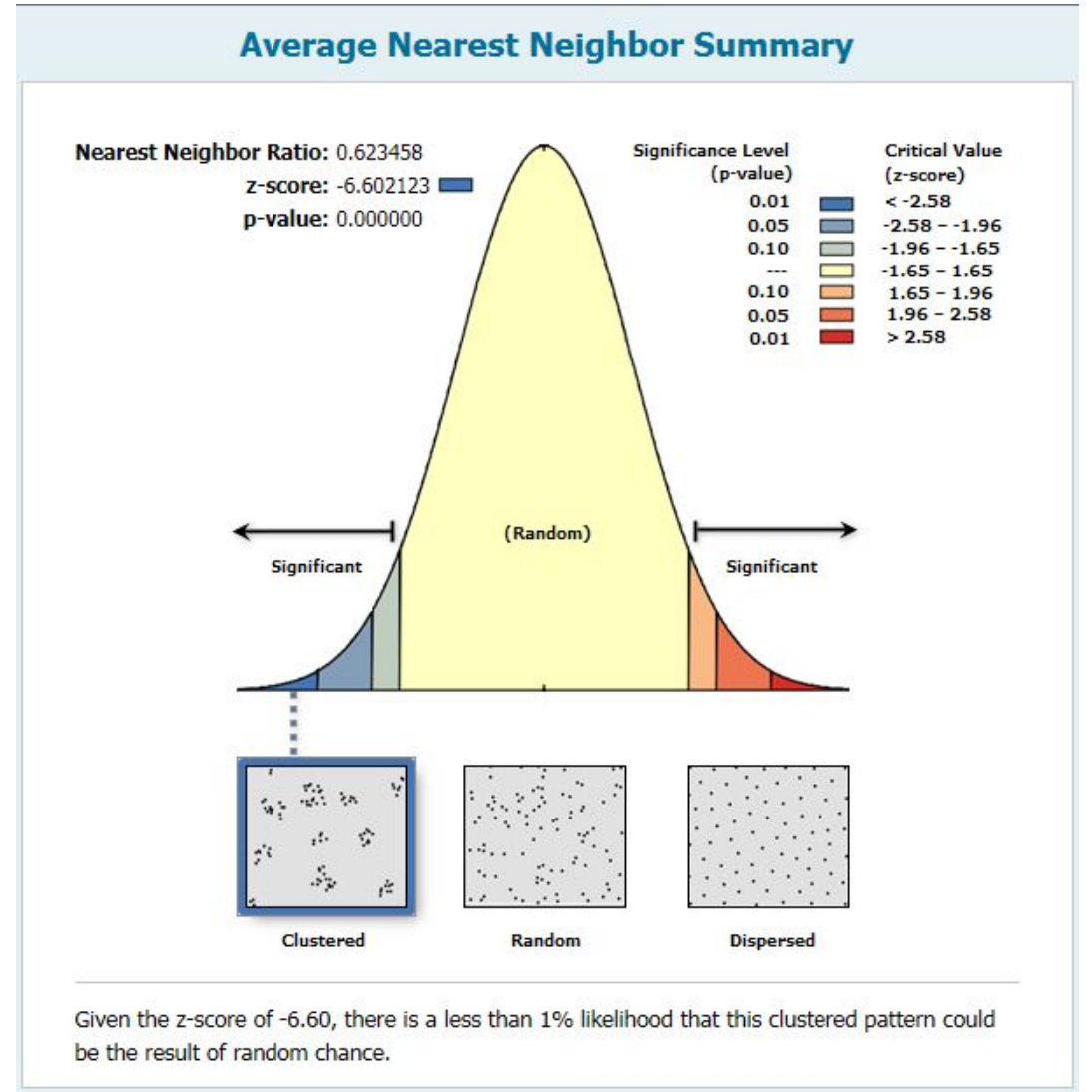

Figure 3. Fatal Accident ANN Analysis Output in the North East District for 2012 
Average Nearest Neighbor Summary

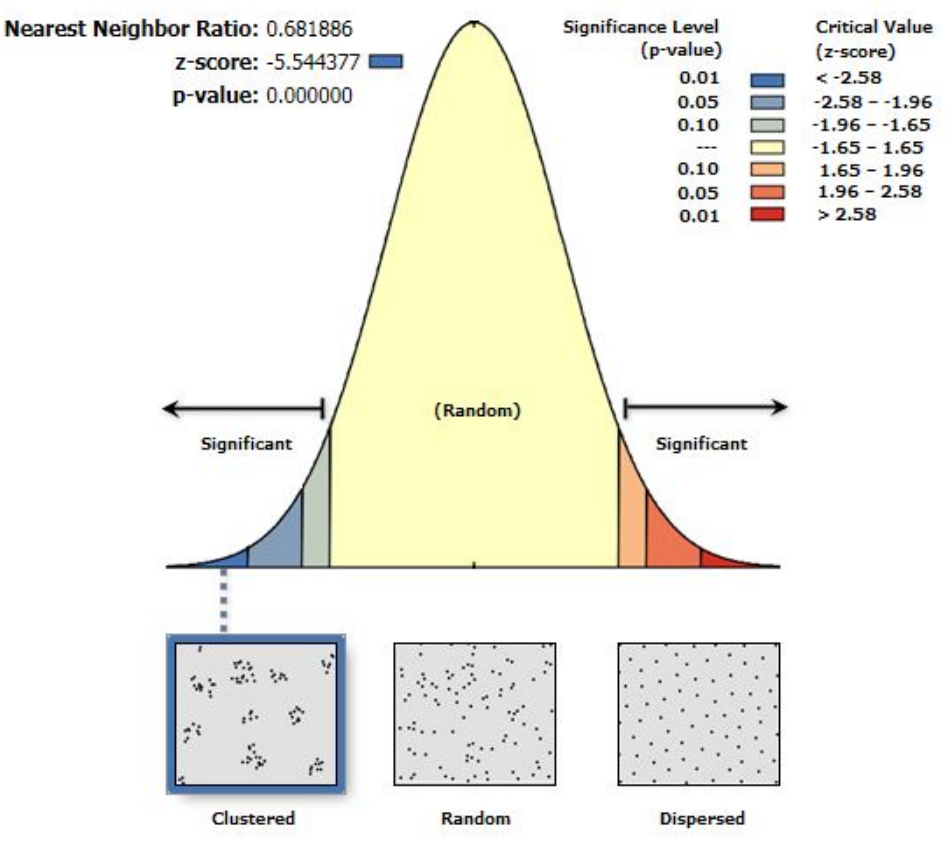

Given the $z$-score of -5.54 , there is a less than $1 \%$ likelihood that this clustered pattern could be the result of random chance.

Figure 4. The Fatal Accident ANN Analysis Output in the North East District in 2013

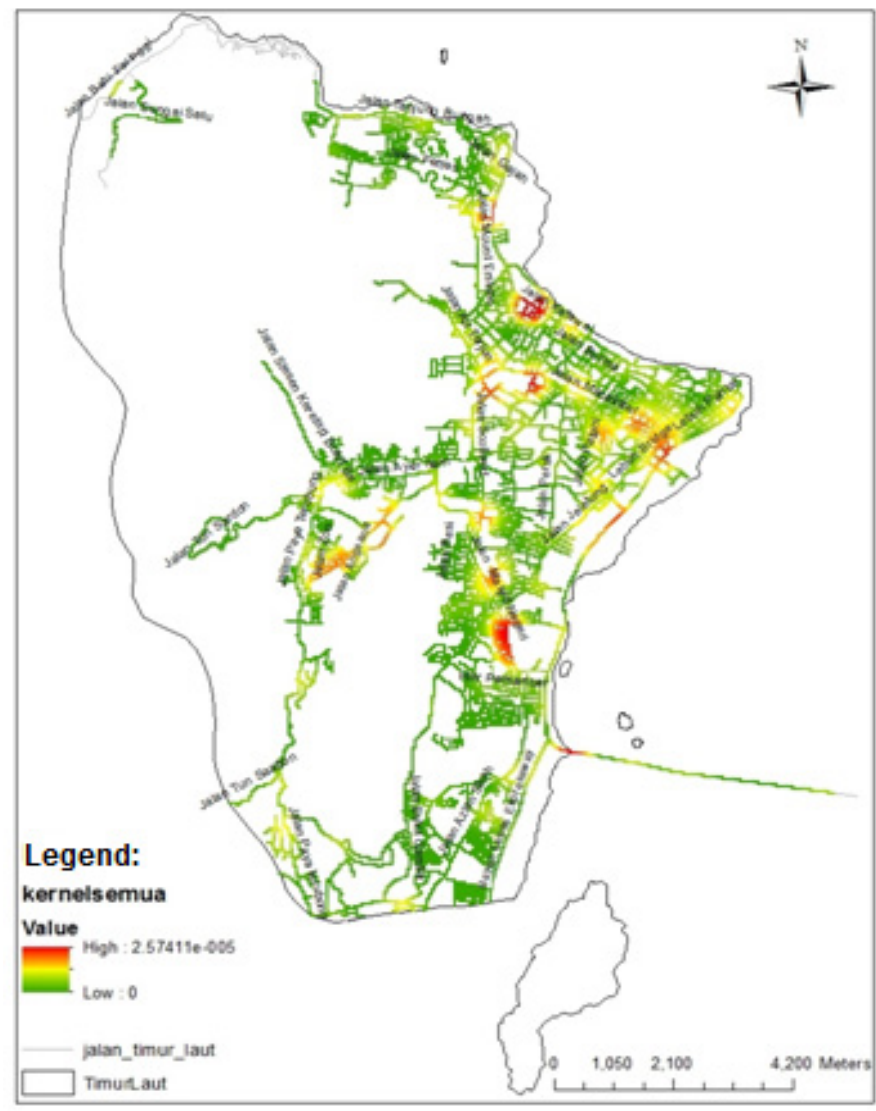

Figure 5. The Research Duration Fatal Accident Black Spot Area 
Table 1. Fatal Black Spot Areas within Study Duration

\begin{tabular}{lll}
\hline Year & Black Spot Area & Sector \\
\hline 2011-2013 & $\begin{array}{l}\text { Sultan Azlan Shah Road until Utara Road junc- } \\
\text { tion at Masjid Negeri Road area }\end{array}$ & Sector 28 and Sector 27 \\
& $\begin{array}{l}\text { Exit to Penang Bridge } \\
\text { Residensi Road from Macalister Road round- } \\
\text { about until the junction towards Tull Road }\end{array}$ & Sector A \\
& $\begin{array}{l}\text { Kelawai Road from Bangkok Lane until Maktab } \\
\text { Road junction }\end{array}$ & Sector and Sector 2 \\
\hline
\end{tabular}

Table 2. Fatal Accident Black Spot Areas within the First Month According to Sectors

\begin{tabular}{lll}
\hline Month & Black Spot Area & Sector \\
\hline First Month & Exit towards Penang Bridge & Sector A \\
& $\begin{array}{l}\text { Thein Teik Highway from Beriksa 3 Street junction until } \\
\text { Medan Angsana 1 Street junction }\end{array}$ & Sector 2 and Sector 4 \\
& $\begin{array}{l}\text { Jelutong Road from Bakau Street junction until Hala } \\
\text { Sungai Pinang }\end{array}$ & Sector 8, Sector 9 and Sector 26 \\
& $\begin{array}{l}\text { C. Y. Cyoi Road from Macallum Street intersection until } \\
\text { Gat Lebuh Nordin intersection }\end{array}$ & Sector 7A \\
& $\begin{array}{l}\text { Residensi Road from Macalister Road roundabout until } \\
\text { Tull Road junction }\end{array}$ & Sector 16 and Sector 36 \\
& $\begin{array}{l}\text { Paya Terubong Road from Bukit Jambul Road junction } \\
\text { until Relau Road junction }\end{array}$ & Sector F \\
& & \\
\hline
\end{tabular}

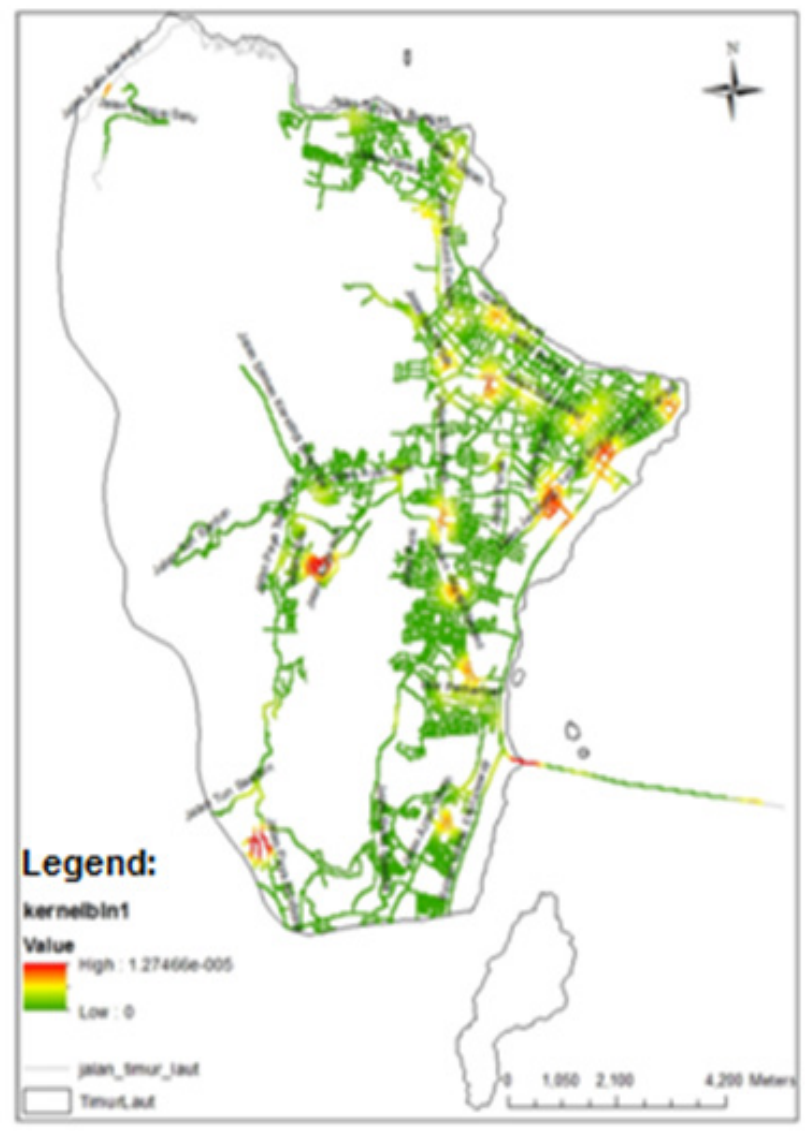

Figure 6. Fatal Accident Black Spot Areas within the First Month 


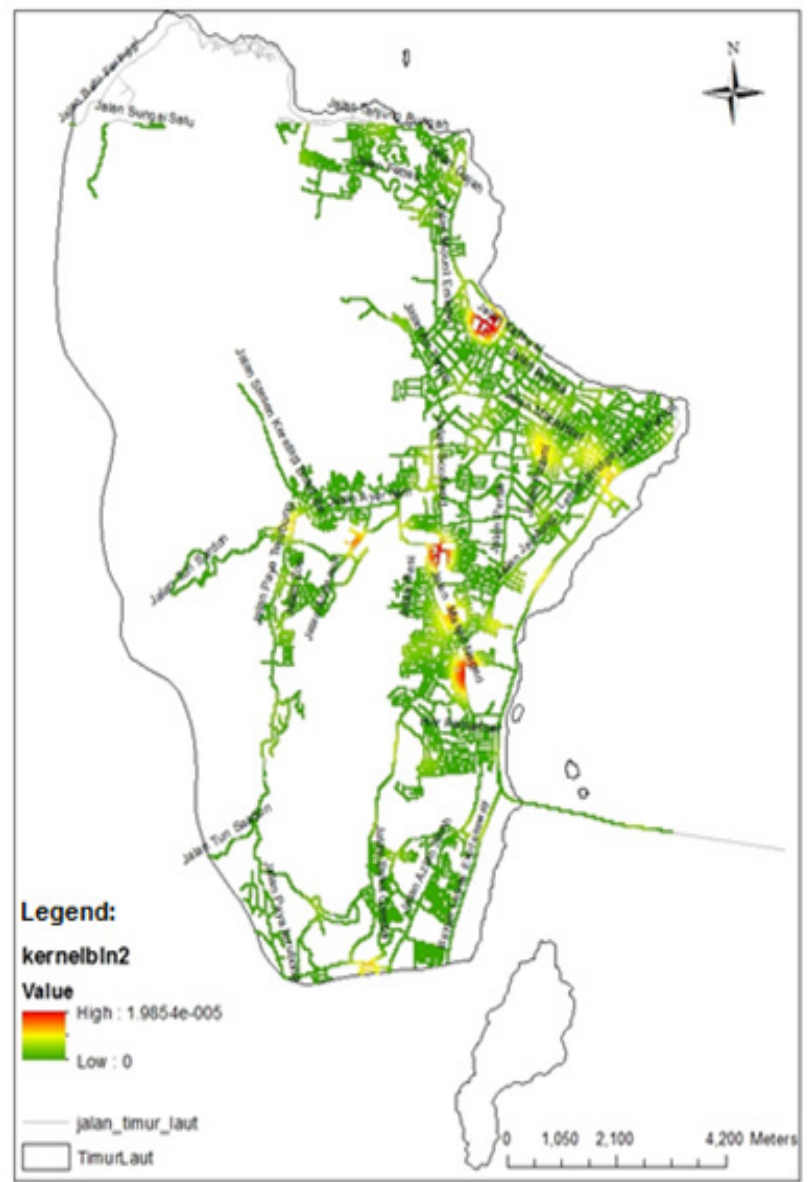

Figure 7. Fatal Accident Black Spot Areas within the Second Month

Table 3. Fatal Accident Black Spot Areas within the Second Month According to Sectors

\begin{tabular}{lll}
\hline Month & Black Spot Area & Sector \\
\hline Second Month & $\begin{array}{l}\text { Sultan Azlan Shah Road from Utara Road junc- } \\
\text { tion until Tengku Kudin Road junction at Gelugor }\end{array}$ & Sector 27 and Sector 28 \\
& $\begin{array}{l}\text { Road area } \\
\text { Masjid Negeri Road from Persiaran Mas junction } \\
\end{array}$ & Sector 6 and Sector 23 \\
& $\begin{array}{l}\text { Kelawai Road from Maktab Road until Bangkok } \\
\text { Lane junction }\end{array}$ & Sector 2 and Sector 6 \\
\hline
\end{tabular}

Table 4. Fatal Accident Black Spot Areas within the Third Month According to Sectors

\begin{tabular}{lll}
\hline Month & Black Spot Area & Sector \\
\hline Third Month & $\begin{array}{l}\text { Thein Teik highway Tun Mohd Salleh } \\
\text { Ismail Road junction until Zoo Road } \\
\text { junction }\end{array}$ & Sector 3 and Sector 4 \\
& $\begin{array}{l}\text { Utama Road from Brook Road intersection } \\
\text { until Scotland Road intersection }\end{array}$ & Sector 36 \\
& Along Thein Teik Road & Sector 1 and Sector 5 \\
\hline
\end{tabular}




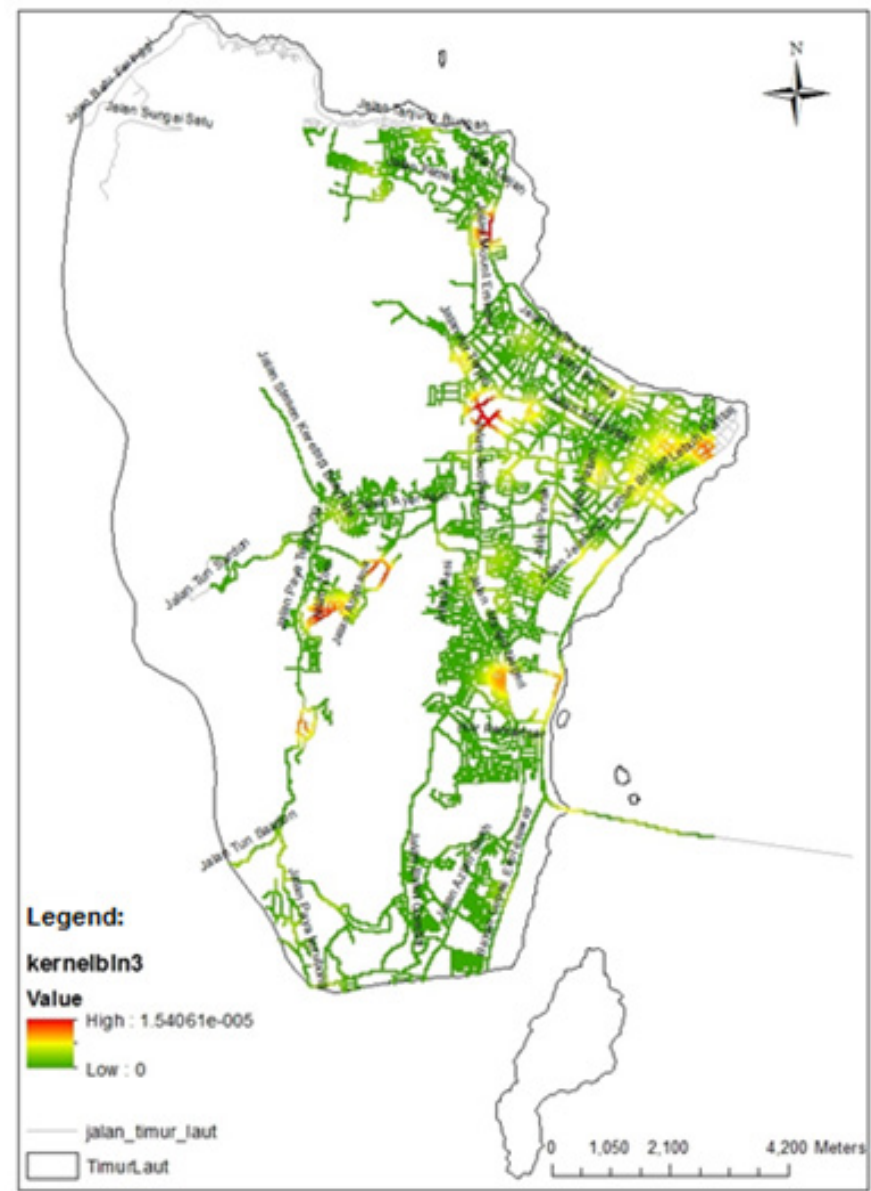

Figure 8. Fatal Accident Black Spot Areas within the Third Month

Table 5. Fatal Accident Black Spot Areas during Nighttime According to Sectors

\begin{tabular}{|c|c|c|}
\hline Time & Black Spot Area & Sektor \\
\hline \multirow[t]{6}{*}{ Day } & $\begin{array}{l}\text { Tun Dr LCE Highway from Cecil Street intersection until } \\
\text { Noordin Street intersection }\end{array}$ & $\begin{array}{l}\text { Sector } 7 \mathrm{~A} \text {, Sector } 7 \mathrm{~B} \text { and Maccal- } \\
\text { lum Booth Sector }\end{array}$ \\
\hline & $\begin{array}{l}\text { Along Penang Road from Dato Keramat Road intersection } \\
\text { until the exit towards Burma Road }\end{array}$ & $\begin{array}{l}\text { Sector } 13 B \text { and Komtar Booth } \\
\text { Sector }\end{array}$ \\
\hline & $\begin{array}{l}\text { Paya Terubong Road from the junction towards Bukit } \\
\text { Kukus Lane until Tingkat Paya Terubong } 4 \text { junction }\end{array}$ & Sector E and Sector F \\
\hline & $\begin{array}{l}\text { Paya Terubong Road from the junction towards Tingkat } \\
\text { Bukit Jambul until Relau Road junction }\end{array}$ & Sector E and Sector F \\
\hline & $\begin{array}{l}\text { Utama Road from Brook Road intersection until Scotland } \\
\text { Road intersection }\end{array}$ & Sector 5 and Sector 36 \\
\hline & Exit towards Penang Bridge & Sector A \\
\hline \multicolumn{3}{|c|}{ Table 6. Fatal Accident Black Spot Areas during Nighttime According to Sectors } \\
\hline Time & Black Spot Area & Sector \\
\hline \multirow[t]{4}{*}{ Night } & $\begin{array}{l}\text { Kelawai Road from the junction towards Bangkok Lane } \\
\text { until Landros Lane junction }\end{array}$ & Sector 2 and Sector 6 \\
\hline & $\begin{array}{l}\text { Residensi Road from Macalister Road roundabout until } \\
\text { Tull Road junction }\end{array}$ & Sector 16 and Sector 36 \\
\hline & $\begin{array}{l}\text { Masjid Negeri Road from the junction towards Persiaran } \\
\text { Mas until the junction towards Pinhorn Road }\end{array}$ & Sector 6 and Sector 23 \\
\hline & $\begin{array}{l}\text { Sultan Azlan Shah Road from the junction towards } \\
\text { Halaman Pemancar until the roundabout towards Tengku } \\
\text { Kudin Road }\end{array}$ & Sector 27 and Sector 28 \\
\hline
\end{tabular}


Terubong 4 junction; Paya Terubong Road area from the junction towards Tingkat Bukit Jambul until Relau Road junction; Utama Road area from Brook Road intersection until Scotland Road intersection; and at the exit towards Penang Bridge area (Figure 9 and Table 5).

The fatal accident black spot areas during nighttime mostly happened at Jalan Kelawei area from the junction towards Bangkok Lane until Landros Lane junction; Residensi Road area from Macalister Road roundabout until Tull Road junction; Masjid Negeri Road area from the junction towards Persiaran Mas until the junction towards Pinhorn Road; and Sultan Azlan Shah Road area from the junction towards Halaman Pemancar until the roundabout towards Tengku Kudin Road (Figure 10 and Table 6).

From the analysis, it shows that the fatal accident spatial pattern for the three years duration of the research is clustered and all the index values are less than 1 . This clearly proves that there is a fatal accident spatial pattern in the North East District and it is found that the pattern is clustered at certain locations. In general, this is due to the different difficulty level for each part of the road caused by a few factors, such as traffic congestion, the importance of certain roads, road geometry, the earth surfaces, etc., which influence individual driving behaviors that could contribute to the causes of fatal accidents (Noor Azam Shairi, 2003; Chao, W. et al., 2009).

It can be generally viewed that the black spot area analysis in this study is focused more towards the difference from the temporal aspect. Among the black spot areas within the study duration of three years were at Sultan Azlan Shah Road area until Utama Road junction; at Masjid Negeri Road area; exit to Penang Bridge; Residensi Road from Macalister Road roundabout until the junction towards Tull Road; and Kelawai Road area from Bangkok Lane junction until Maktab Road junction. The research output is aligned with the output obtained by Erdogan et al. (2009) who use the same analysis and have proven that road segment junction areas are where accidents frequently occur. All these road areas are busy areas as they are the main ways to get to the focal population areas: such as George Town city center; the state government administrative centers like Komtar, Penang General Hospital; shopping centers like Gurney Plaza; and to exit to Seberang Perai through Penang Bridge.

There are also differences in terms of locations of the black spot areas according to month. On the first month, there were more black spot areas which were at 6 road areas, in comparison to the second and third month. In the second and third month, each had 3 fatal accident black spot areas. Within the first month, almost all main roads in the North East District had high accident density clusters which include: exit road towards Penang Bridge area; Thein Teik Highway area; C. Y. Choi Road area; Residensi Road; Paya Terubong Road area; and Sultan Azlan Shah Road area. Within the second month, only Sultan Azlan Shah Road area had high fatal accident density and the rest of the black spot areas within the second month were focused on Masjid Negeri Road and Kelawai Road areas. Within the third month, the black spot areas were clustered in the West side of the study areas which include Thein Teik Highway area, along Jalan Thein Teik and Utama Road areas. This shows that the differences in the months within the duration of the three year study also influence the black spot area locations involving fatal accidents in North East District. This study illustrates a more qualitative output, where the fatal accident black spot area locations are interpreted by looking at the areas or segments of roads that show high density, compared to other road segments. This method is aligned with the output interpretation done by Mark et al. (2013) in their research on Quezon City.

Moreover, this research also illustrates the differences among the fatal accident black spot areas based on the time factor, which is between daytime and nighttime. The Kernel density raster map outputs based on daytime and nighttime shows interesting results. There are clear differences in the fatal accident black spot area locations. The analysis shows that the number of black spot areas is higher during daytime and big portion exists at the main roads within the study areas, whereas the fatal accident black spot areas during nighttime centers only at the middle section of the study area. The higher number of black spot areas during daytime is due to almost all the main roads becoming focal areas for road users, particularly as roadways for their daily activities such as to go to work, visiting tourist spots and others. At nighttime, only certain roads become focal points, especially roads that connect to shopping complexes, rest and recreation areas, restaurants, etc. All these are places people frequent after the long hard day at work. Hence, it is not surprising that fatal accidents at night only center at Sultan Azlan Shah Road and Masjid Negeri Road areas as these roads are the main roadways from the Southern and Northern areas of the study area, and they are very much focal points during nighttime. This is because, within the Northern study area, there are shopping complexes and recreational places such as Gurney Plaza, Persiaran Gurney, Batu Feringghi, etc. These are particular attraction spots for people in the evening. At the Southern area, the roads connect to the South West District where Queensbay Mall, a shopping complex that is frequently visited, and a coastal area nearby. These are other attractions for the people to shop and relax, particularly at night. Other than that, the research output also shows that the main factor for fatal accidents to happen at night is higher as the traffic flow rate around the area is high compared to other influencing factors such as the earth surfaces and road physical conditions. Fatal accidents in the nighttime are more clustered at main roads that have flat surfaces, better road physical conditions such as good street 


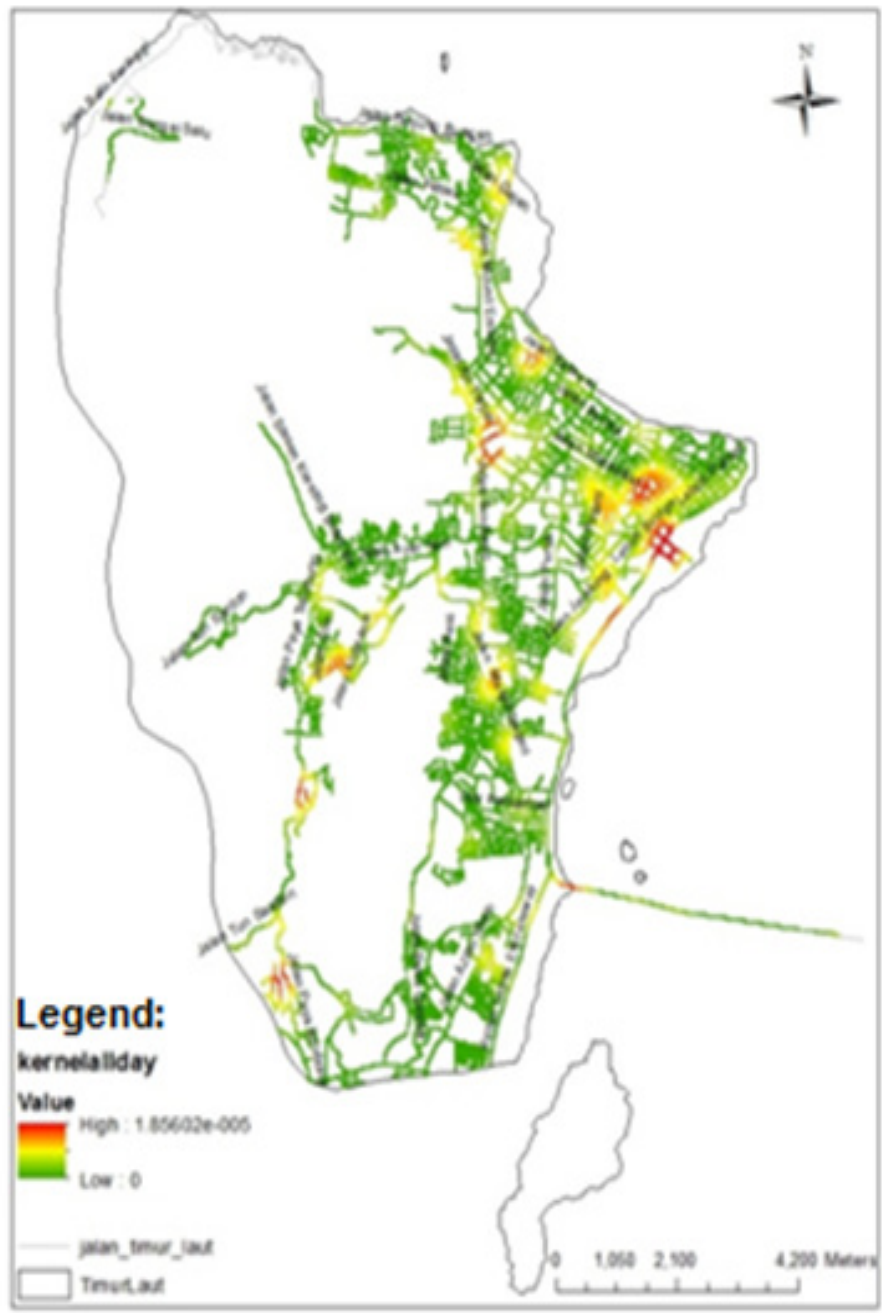

Figure 9. Fatal Accident Black Spot Areas during Daytime

lighting, road width, and safety road signage, compared to roads that are uneven, lack good lighting and are narrow.

\section{Conclusion}

The use of GIS is able to help the safety field, particularly in determining accident cases that happen within a study area. This is because GIS could be made as a useful database that could store spatial and non-spatial data linked to road accidents. The output displayed through GIS is a model or an actual representative of the real happenings in particular areas. Furthermore, GIS usage is faster, and the obtained results also are easily understood by all levels of consumers as it displays the information in the form of clear and attractive maps.

\section{Acknowledgments}

The completion of this research article could not have been possible without the participation and assistance of so many parties and people whose names may not all be enumerated. The contributions are gratefully acknowledged and sincerely appreciated by us. Hence, we would like to express our special thanks to Universiti Malaysia Sarawak (UNIMAS). We would also like to thank the Penang Police Contingent Headquarter and everyone whom we have had the pleasure to work with during conducting this research.

\section{References}

Apparao, G. P. \& Mallikarjunareddy, G. R. (2013). Identification of Accident Black Spots for National Highway Using GIS. International Journal of Scientific \& Technology Research. Vol. 2(2). pp. 154-157.

Brockenbrough, R. (2009). Highway safety engineering (3rd ed.). New York: McGrawHill.

Chao, W., Mohammed, A. Q. \& Stephen G. I. (2009). Impact of Traffic Congestion on Road Safety: A Spatial Analysis of The M25 Motorway in England. Accident Analysis and Prevention. Vol. 41, pp. 798-808. 
Clinton, V. \& John, S. (2013). Analyzing Road Safety in the United States. Research in Transportation Economics. Vol. 43, pp. 98-111.

Elvik, R., Hoye, A., Vaa, T., \& Sorensen, M. (2009). The handbook of road safety measures (2nd ed.). Bingley, UK: Emerald Group Publishing.

Erdogan, S. (2009). "Explorative Spatial Analysis of Traffic Accident Statistics and Road Mortality Among The Provinces Of Turkey." Journal of Safety Research. Vol. 40(5) pp. 341-351.

Fuller, R. (2000). The Task-Capability Interface Model of The Driving Process, Recherche Transports $S^{\prime}$ ecurit' e 66, 47-59.

Fuller, R., Santos, J.A. (2002). Psychology and The Highway Engineer. In: Fuller, R., Santos, J.A. (Eds.), Human Factors for Highway Engineers. Pergamon, Oxford, pp. 1-10.

Mark, R. D. L., Nelson, D., Hussein, L. \& Jun, C. (2013). Black Spot Cluster Analysis Of Motorcycle Accidents. Proceedings of the Eastern Asia Society for Transportation Studies. Vol. 9.

Masron, T., Yaakob, U., Ayob, N. M., \& Mokhtar, A. S. (2012). Population and spatial distribution of urbanisation in Peninsular Malaysia 1957 - 2000. Malaysia Journal of Society and Space. 8(2). 20-29.

McGranahan, G. \& Satterthwaite, D. (2014). Urbanisation concepts and trends. International Institute for Environment and Development. 80-86 Gray's Inn Road, London WC1X 8NH, UK.

Mohamad Naim, Mazrura Sahani, Hidayatulfathi Othman, Rozita Hod, Shaharudin Idrus, Zainudin Mohd Ali, Er Ah Choy \& Mohd Hafiz Rosli (2013). Aplikasi Sistem Maklumat Geografi Untuk Pemetaan Ruang-masa: Suatu Kajian Kes Denggi Daerah Seremban, Negeri Sembilan, Malaysia. Sains Malaysiana. Vol. 42(8). pp. 1073-1080.
Nordin, M. N. \& Masron, T. (2016). Analisis ruangan hotspot penyalahgunaan dadah di Malaysia: Kajian kes Daerah Timur Laut, Pulau Pinang. Malaysian Journal of Society and Space. 12(5). $74-82$.

Noor Azam Shairi (2003). Rencana. Utusan Express. Kuala Lumpur.

OECD (2014). Road Safety Annual Report 2014. International Transport Forum. Dilayari pada 16 November 2014. Website: http:// www.internationaltransportforum.org/pub/ pdf/14IrtadReport.pdf.

Oulha, R., Brahimi, K., Boumediene, A., Dali, F. \& Madouche, M.A. (2013). GIS contributing To Identify Accident Black Spots on National Highway: Case Study Of Wilaya Of Mascara. International Journal of Chemical, Environmental \& Biological Sciences (IJCEBS).Vol. 1 (5). pp. 775-778.

Rankavat, S. \& Tiwari, G. (2013). Pedestrian Accident Analysis in Delhi Using GIS. Proceeding of The Eastern Asia Society for Transportation Studies. Vol. 9.

Sabel, C. E., Simon, K., Alan, N. \& Phil, B. (2005). Road Traffic Accident Simulation Modeling-A Kernel Estimation Approach, Presented At SIRC 2005 (November). The 17th Annual Colloquium of The Spatial; Information Research Centre University Of Otaga, Dunedin. New Zealand.

WHO (World Health Organisation (2009). Global Status Report On Road Safety. 20 Avenue Appia, Geneva 27. Dilayari pada 16 November 2014.Website: www.who.int/violence_injuiry_prevention.

Yue, W. L. \& Zhang, M. F. (2001). The Use of GIS In Black Spot Studies. Eastern Asia Society For Transportation Studies. Vol. 4. pp. 285-292. 